This is a final draft of an article that was published by Oxford University Press in the Oxford Research Encyclopedia of Religion. For referencing, please use the final version from OUP:

Hanner, Oren. "Abhidharmakośabhāșya (Treasury of Metaphysics with Self-Commentary)." In Oxford Research Encyclopedia of Religion. Oxford University Press, 2014-. Article published March 25, 2021. doi: https://doi.org/10.1093/acrefore/9780199340378.013.718.

\title{
Abhidharmakośabhāșya (Treasury of Metaphysics with Self-Commentary)
}

\author{
Oren Hanner
}

\section{Summary}

The Abhidharmakośabhāșya (Treasury of Metaphysics with Self-Commentary) is a pivotal treatise on early Buddhist thought composed around the fourth or fifth century by the Indian Buddhist philosopher Vasubandhu. This work elucidates the Buddha's teachings as synthesized and interpreted by the early Buddhist Sarvāstivāda school ("the theory that all [factors] exist"), while recording the major doctrinal polemics that developed around them, primarily those points of contention with the Sautrāntika system of thought ("followers of the scriptures"). Employing the methodology and terminology of the Buddhist Abhidharma system, the Abhidharmakośabhāṣya offers a detailed analysis of fundamental doctrines, such as early Buddhist theories of mind, cosmology, the workings of karman, meditative states and practices, and the metaphysics of the self. One of its unique features is the way it presents the opinions of a variety of Buddhist and Brahminical schools that were active in classical India in Vasubandhu's time. The work contains nine chapters (the last of which is considered to have been appended to the first eight), which proceed from a description of the unawakened world via the path and practices that are conducive to awakening and ultimately to the final spiritual attainments which constitute the state of awakening. In its analysis of the unawakened situation, it thus covers the elements which make up the material and mental world of sentient beings, the wholesome and unwholesome mental states that arise in their minds, the structure of the cosmos, the metaphysics of action (karman) and the way it comes into being, and the nature of dispositional attitudes and dormant mental afflictions. In its treatment of the path and practices that lead to awakening, the treatise outlines the Sarvāstivāda understanding of the methods of removing defilements through the realization of the four noble truths and the stages of spiritual cultivation. With respect to the awakened state, the Abhidharmakośabhāșya gives a detailed description of the different types of knowledge and meditational states attained by practitioners who reach the highest stages of the path.

Keywords: Abhidharma, Buddhism, Sarvāstivāda, Sautrāntika, Vaibhāșika, Vasubandhu 
The Abhidharmakośabhāṣya (Treasury of Higher Knowledge with Self-Commentary; often abbreviated as $A K B h$ ) is an influential treatise on early Buddhist doctrine, composed around the end of the fourth century $A D$ by the prominent Indian philosopher Vasubandhu (fourth to fifth centuries $A D$ ). The work systematically lays down the philosophical views of two key early Buddhist philosophical systems - the Sarvāstivāda (literally "the theory that all [factors] exist") and the Sautrāntika ("followers of the sutras [the Buddha's discursive teachings]") - while scrutinizing the stances of other Buddhist and non-Buddhist intellectual circles. Consisting of nine chapters, the $A K B h$ delineates the knowledge required for spiritual liberation (nirvāna) from the cycle of births and deaths by analyzing the various material and mental factors (dharmas) characterizing the non-awakened state of sentient beings, those pure factors by virtue of which liberation is attainable, and the spiritual path and practices conducive to this goal.

The Abhidharma genre, to which Vasubandhu's work belongs, aims to achieve two main goals: first, to systematize the Buddha's diverse teachings as preserved in the early sutra corpus, and second, to determine thereby the Buddha's ultimate doctrines, those doctrines which do not require further explication (nitārtha) and which therefore correspond to ultimate reality as it is. To this end, Abhidharma analysis employs exegetical devices as a matter of usual practice, leading to diverging opinions regarding its most essential subject matters. The $A K B h$, in this respect, touches on key doctrinal controversies debated in the Abhidharma literature. Among the contested issues are the existential status of selves (ātman) or persons (pudgala, AKBh IX); the question of whether factors exist in the past and future (AKBh V:24-27); the claim that noninformative matter (avijñapti-rūpa) is a distinct ultimate factor ( $A K B h$ IV:4); and the problem of whether latent tendencies are synonymous with active defilements or whether these are two different states (AKBh $\mathrm{V}: 2)$.

In terms of structure, the work is made up of nearly 600 verses - referred to as the Abhidharmakośakarikā $(A K)$ - and Vasubandhu's prose self-commentary (bhāṣya). It is generally accepted by both tradition and modern scholars that the verse portion summarizes the Sarvāstivāda's understanding of the Buddha's teachings (and more precisely that of the northern sub-sect, called the Vaibhāșika, "followers of the Great Commentary"), while the prose portion critiques components of this interpretation from a Sautrāntika point of view. There are, however, numerous places where the author accedes to Vaibhāșika doctrines, and some traditional commentators maintain that he did not affiliate himself with one school of thought, but rather proclaimed that which was in accordance with the truth, whether taught by the Vaibhāșika or by Sautrāntika. ${ }^{1}$ At any rate, when Vasubandhu repudiates the Vaibhāșika standpoint, it is often with respect to the ultimate entities postulated by this school - unnecessarily, according to the Sautrāntika. In cases where the Vaibhāșika accounts for a phenomenon in this way, the Sautrāntika favors an explication based on causality or temporal processes.

Although historically the $A K B h$ constitutes one link in a chain of Abhidharma treatises, it came to the fore and overshadowed its predecessors not long after its composition, becoming the standard reference work for Buddhist scholars studying Abhidharma topics. Thus, it exerted great influence on East Asian traditions, and, once translated into Tibetan, it was accepted as the main representative of this literature in Tibetan Buddhism. 


\section{A Textual History of the Abhidharmakośabhāșya}

The $A K B h$ owes much of its structure and thematic organization to a series of manuals composed during earlier stages of the Sarvāstivāda Abhidharma tradition. In particular, Vasubandhu appears to have modeled his composition on works belonging to the Gandhāran Hrdaya (heart or essence) series of treatises. The fundamental stratum in the Abhidharma corpus of the Sarvāstivāda - its Abhidharma-pițaka - comprises seven scriptures, the chief of which is the Jñānaprasthāna, ascribed to Kātyāyanīputra. The school developed in two main directions, corresponding to two geographical areas in which its thought dominated. One sub-group was active in Kashmir and particularly venerated the Mahāvhibhāșā, a voluminous commentary on the Jñānaprasthāna, from which this group acquired its appellation, the Vaibhāșika. A second sub-group of the Sarvāstivāda was concentrated around Bactria and Gandhāra and produced a number of Abhidharma compilations known as the *Abhidharmahrdaya (the heart or essence of the Abhidharma), today extant only in their Chinese translations.

The first of these compilations is the *Abhidharmahrdaya, ascribed to Dharmaśri or Dharmaśreșțin (ca. 200 AD). This text's main innovation lies in the systematization of the doctrine of the Gandhāra sub-school and the summarizing of its tenets in the form of verses. The *Abhidharmahrdaya also makes reference to the views of other Sarvāstivāda groups. It consists of ten chapters of 250 verses and their commentaries. A commentary on this treatise titled *Abhidharmahrdaya or Abhidharmahrdayaśāstra was composed by Upaśānta. This commentary adopts the structure of its root text, including the division into ten chapters, but adds a number of verses, amounting to 249 in total. Upaśānta's work was followed by a third treatise, the *Samyuktābhidharmahṛdya or *Miśrakābhidharmahrdaya, which is attributed to Dharmatrāta and is considered to have been composed in the first half of the fourth century. ${ }^{2}$ This work adds one chapter to the total of eleven chapters and expands the number of verses to 596, thereby offering a doctrinal elaboration of the first two treatises. The $A K B h$, together with most of the theoretical problems, polemics, and questions it addresses, stems from these three Hrdaya treatises.

Willemen, Dessein, and Cox distinguish between four kinds of texts in Sarvāstivāda Abhidharma literature, each of which exhibits a different degree of development in regard to doctrinal exposition: simple expository texts; texts which adopt more abstract principles of organization; highly polemical works identifying the positions of contending groups; and dialectical expository treatises that summarize the doctrinal position of the philosophical school or sub-school to which they belong. According to their analysis, the Hrdaya literature - including the AKBh - displays elements of the fourth stage of development. ${ }^{3}$

One figure who played an essential role, albeit chiefly adversarial, in the intellectual development of the $A K B h$ is the Vaibhāșika scholar Samghabhadra. According to traditional accounts, after composing the $A K$ (verse portion), Vasubandhu sent it to this master, who approved its accuracy and compatibility with the philosophical tenets of the Vaibhāșika and encouraged the composition of the self-commentary. ${ }^{4}$ Having later realized that the commentary was in disagreement with important Sarvāstivāda principles, Samghabhadra wrote two treatises of his own with rejoinders to Vasubandhu's Sautrāntika arguments. The two works - the *Nyāyānusāra (Taisho 1562$)^{5}$ and the *Abhidharmasamayapradīpikā (Taisho 1563) - were translated by Xuanzang and are preserved in their Chinese translations alone.

In the centuries that followed, the $A K B h$ was translated from Sanskrit into other Asian languages and, beginning from the twentieth century, also into European languages. In pre-modern times, it 
was translated into Chinese twice: first between 563 and 567 AD by Paramārtha (Taisho 1559) and a second time between 651 and 654 AD by Xuanzang (Taisho 1558). ${ }^{6}$ In the ninth century, the work was translated from Sanskrit into Tibetan by Jinamitra and Ska ba dPal brtegs (chos mngon pa'i mdzod kyi bshad pa, Derge 4090). Around the end of the eleventh century, a second translation into Tibetan was produced by Smritijñānakīrti, but this was not included in the Tibetan Tanjur collection. ${ }^{7}$

Modern scholarship has produced a number of critical editions of the $A K$ or $A K B h$ in Sanskrit. Described chronologically, it was first edited as part of a critical edition of Yaśomitra's commentary, Sphuțārthābhidharmakośavyākhyā (whose original contains the verse portion of the $A K)$, produced by Unrai Wogihara between 1932 and $1936 .{ }^{8}$ A decade later, in 1946, V. V. Gokhale edited the verse section of the work based on the then newly found Sanskrit manuscript of the AKBh. ${ }^{9}$ The standard Sanskrit edition of this text is Prahlad Pradhan's 1967 edition of both the verse and auto-commentary sections of the work. ${ }^{10}$ It was followed by a second edition eight years later, which suffers from various mistakes that are not present in the first edition. ${ }^{11}$ Finally, Dwarakidas Shastri edited the verse and auto-commentary sections of the $A K B h$ alongside Yaśomitra's Vyākhyā. This edition appeared in print between 1970 and $1973 .{ }^{12}$ Lee (2005) provides a critical edition of the ninth chapter of the $A K B h .^{13}$ In addition to the above editions of the Sanskrit text, an important edition of Xuanzang's Chinese translation was prepared by the Japanese scholar-monk Kyokuga Saeki and published in $1886 .{ }^{14}$ In this annotated edition, Saeki references Puguang's and Fabao's commentaries and identifies the scholastic affiliation of philosophical positions expressed in the $A K B h$. This edition also includes a translation of the work into Japanese.

Until the 1930s, when a Sanskrit manuscript was found by Rahul Sanskrityayan, the $A K B h$ was known only through its Chinese and Tibetan translations. The first translation of the AKBh into a European language was made shortly before the finding of the Sanskrit manuscript. This is the monumental French translation by Louis de la Vallée Poussin, which was published between 1923 and $1931 .{ }^{15}$ La Vallée Poussin's reading is primarily based on the Chinese version of Xuanzang as elucidated in Saeki's edition, but it relied on other sources for the assessment of the text's meaning. This includes Yaśomitra's Sanskrit commentary, Paramārtha's Chinese translation, and the two extant Tibetan translations. ${ }^{16}$ Later, between 1988 and 1990, La Vallée Poussin's French edition was translated into English by Leo Pruden, ${ }^{17}$ and a more recent translation was produced in 2012 by Gelong Lodrö Sangpo, who also consulted the Sanskrit manuscript and additional secondary literature on the AKBh. ${ }^{18}$ Also published in 2012 is an English translation from the Tibetan by David Karma Choephel, which includes the root verses and a commentary by the ninth Karmapa, Wangchuk Dorje (albeit without Vasubandhu's bhāșya). ${ }^{19}$ Finally, a recent English translation of the $A K B h$, as preserved in the language of Uighur - itself a translation of Xuanzang's Chinese rendering - was undertaken by Masahiro Shōgaito and published in $2014 .^{20}$

Because of its high philosophical value, as well as its relevance to Western philosophical discourses on personal identity, the ninth chapter of the $A K B h$ has been separately translated into English several times. Published translations include Theodore Stcherbatsky's 1919 "The Soul Theory of the Buddhists"21 (from Tibetan), Matthew Kapstein's rendering in his 2001 Reason's Traces $^{22}$ (from Tibetan, with reference to the Sanskrit text), a translation and modern commentary by James Duerlinger in Indian Buddhist Theories of Persons, ${ }^{23}$ published in 2003 (from Sanskrit), and Charles Goodman's translation from 2009, which includes the second half of the chapter (from Tibetan). ${ }^{24}$

Modern Japanese scholarship has produced an extensive literature on the $A K B h$, including translations of the text and helpful research tools. Two important translations of the entire work 
from Chinese (Xuanzang's edition) are Taiken Kimura and Unrai Wogihara's translation from 1920 and Giyū Nishi's translation from $1935 .{ }^{25}$ A series of translations from Sanskrit into Japanese offers the most complete translation into a modern language directly rendered from the original Sanskrit. The series includes Hajime Sakurabe's (1969) translation of chapters 1 (on the factors, dhātu) and 2 (on the faculties, indriya); Susumu Yamaguchi and Issai Funahashi's (1955) translation of chapter 3 (on the world, loka); Funahashi's (1987) rendition of chapter 4 (on karman); Nobuchiyo Odani and Yoshifumi Honjō's (2007) translation of chapter 5 (on latent dispositions, anuśaya); and Sakurabe and Odani's (1999) translation of chapter 6 (on the path and persons, mārgapudgala) and (2004) of chapters 7 (on knowledge, jñāna) and 8 (on meditative attainments, samāpatti). ${ }^{26}$ Each of the translations in the series is collated with the respective Tibetan and Chinese translations, and, apart from Sakurabe's translation (1969), includes a translation of Yaśomitra's commentary on the respective chapter. The translations are based on Pradhan's critical edition, apart from Yamaguchi and Funahashi's (1955), which relies on the citation of the $A K B h$ in Yaśomitra's Sanskrit commentary.

Between 1973 and 1978, Akira Hirakawa, along with a group of scholars, produced a trilingual index of the $A K B h .{ }^{27}$ Part I of the index follows the order of the Sanskrit terms, with their Chinese and Tibetan equivalents, while part II follows the order of Chinese terms, offering the Sanskrit equivalent for each. In part III, the words are indexed according to the Tibetan vocabulary and their Sanskrit original. Another project, which was accomplished in the 2010s as part of the Bauddhakośa series, surveys the 75 dharmas of the Sarvāstivāda as enumerated in the $A K B h$. The work provides a Sanskrit-Tibetan-Chinese-English glossary, illustrates each of the terms with examples from the $A K B h$ and Yogācāra literature, and links them to other reference works. The printed edition was published in $2018,{ }^{28}$ while an electronic version from 2014 is available online. ${ }^{29}$

\section{The Structure and Content of the Abhidharmakośabhāșya}

The $A K B h$, as it has come down to us, is made up of nine chapters: the specification of factors (dhātu-nirdeśa), the specification of faculties (indriya-nirdeśa), the specification of the world (lokanirdeśa), the specification of action (karma-nirdeśa), the specification of latent dispositions (anuśaya-nirdeśa), the specification of paths and persons (mārgapudgala-nirdeśa), the specification of the liberating forms of knowledge (jñāna-nirdeśa), the specification of attainments (smāpatti-nirdeśa), and the refutation of the theory of self (titled Ātmavāda-pratiședha by Vasubandhu and Pudgala-viniścaya in Yaśomitra's commentary). The final chapter is considered to have been composed as an independent treatise and added later as an appendix to the first eight chapters. An indication of this is its distinct form, which, unlike the rest of the $A K B h$, does not develop the philosophical investigation on the basis of root verses, but applies prose only, and Vasubandhu's concluding verses at the end of the eighth chapter of the work. The AKBh also deviates from its predecessors in its third chapter on the world, which is absent from earlier Hrdaya treatises.

Both traditional and modern thinkers have surmised the principle that guides this precise order of chapters. According to the Chinese commentator Puguang, the AKBh aims to elucidate the doctrine that all dharmas are without a self. The first two chapters clarify this truth with respect to both pure and impure factors; chapters 3 to 5 do the same with respect to impure factors, while chapters 6 to 8 elucidate this principle with reference to pure factors, and the final chapter gives a general explanation of the teaching of no-self. ${ }^{30}$ In the Collection of Records concerning the 
Tripitaka (Chu sanzang ji ji, Taisho 2145), the sixh-century Chinese translator Jiaojing correlated the order of the *Smayuktābhidharmahrdaya, on which the $A K B h$ is modeled, with the order of the four noble truths. On this analysis, the first chapter of the $A K B h$ on the elements centers on the noble truth of suffering; the second, fourth, and fifth chapters correspond to the noble truth of the origin of suffering; the sixth chapter centers on the noble truth of the cessation of suffering; and the seventh and eighth chapters correspond to the noble truth of the path to the cessation of suffering. Chapters 3 and 9 , according to this organizing factor, are additional chapters. ${ }^{31}$ Welleman, Dessein, and Cox (1997, p. 274), building on a scheme drawn up by Funahashi (1961), ${ }^{32}$ propose that the $A K B h$ can be divided into three parts. The first - comprising chapters 1 and 2 - elaborates on the nature of dharmas; the second - comprising chapters 3 to 5 elucidates the illusional world (or the reasons that beings remain within the cycle of births and deaths); while the third - consisting of chapters 6 to 9 - explains the awakened world (or the path that leads sentient beings out of illusion).

In terms of content, the first chapter of the work gives an overview of the variety of conditioned and unconditioned factors (dharmas) that are constitutive of sentient existence. To explain the first of the two categories, Vasubandhu lays out three key models through which conditioned factors are classified. The first is the scheme of the five aggregates (skandha). These are the five principal aspects or functions of sentient existence and include the aggregates of matter (rūpa), feelings (vedanā), cognitions (saṃjñā), formations (saṃskāra), and consciousness (vijñāna). Conditioned factors can also be classified according to the model of the twelve sense-spheres (āyatana), which consist of the six sense organs (the eye, ear, tongue, nose, body, and mind) and their six corresponding objects (objects of sight, hearing, taste, smell, touch, and the mind), as well as according to the eighteen elements (dhātu), which consist of the twelve sense spheres with the addition of the six types of consciousness. ${ }^{33}$

The second chapter presents three related topics, beginning with an exposition of the twenty-two controlling faculties (indriya) - elements which exercise control over particular domains of sentient life. The list describes the six sense faculties, the male and female sex faculties, the faculty of life force, five feeling faculties (displeasure, pleasure, dissatisfaction, satisfaction, and equanimity), five spiritual faculties (faith, energy, mindfulness, meditative absorption, and wisdom), and three pure faculties, whose domain is spiritual attainment. The second part of the chapter opens by providing the Vaibhāșika list of factors, which contains seventy-five entries and is organized according to the five categories of matter (rūpa), mind (citta), thought concomitants (caitasika), conditioned factors dissociated from the mind (cittaviprayukta), ${ }^{34}$ and unconditioned factors (asamskrta). Vasubandhu then goes into a more in-depth examination of the modes of arising of different conditioned factors which come into being simultaneously. This particularly concerns the coexistence of mind moments (citta) and the thought concomitants accompanying them. The discussion of simultaneous arising paves the way to the more general topic of causality, wherein the $A K B h$ investigates the different types of causes and effects identified by Buddhist and nonBuddhist schools of the time. Vasubandhu recognizes five types of effects: ripened effect (vipākaphala), effect of equal outflow (nișyandaphala), effect of disconnection (visamyogaphala), effect of human action (purușakāraphala), and effect of dominance (adhipatiphala). He also identifies six types of causes: efficient cause (kāraṇahetu), co-existent cause (sahabhūhetu), homogeneous cause (sabhāgahetu), associated cause (samprayuktahetu), pervasive cause (sarvatragahetu), and ripening cause (vipākahetu). According to Vasubandhu, all six types of causes are ultimately efficient causes. 
In the third chapter, the $A K B h$ deals with the universe and the place of sentient beings within it according to Buddhist cosmology. Vasubandhu describes the threefold world in which sentient beings may be born, which comprises the realms of desire (kāma-dhātu), fine materiality (rūpyadhātu), and non-materiality (arūpya-dhātu). In light of the significance of transmigration for the reality of non-awakened beings, Vasubandhu elaborates on the planes of existence - particular forms of existence within the three realms - and the intermediate state, in which beings abide from the time of their death until a subsequent rebirth. The doctrine of dependent origination (pratitya-samutpāda), with its twelve links, explains the causal manner in which sentient beings take new rebirths and persist in cyclic existence in the absence of an enduring self. ${ }^{35}$ Alongside this explanation of the sentient universe, Vasubandhu draws the landscape of the receptacle world (bhājana-loka), the physical world that contains sentient existence - Mount Sumeru, which stands at the center of the universe, the continents, oceans, and other mountains - and describes the universe's temporality: its cyclic creation and dissolution.

In the famous passage that opens the fourth chapter, Vasubandhu proclaims that the world of sentient beings results from their actions (karman). Thus, this part of the $A K B h$ sets out to explicate the metaphysics of action and its results according to Abhidharmic analysis and sutra teachings. The first issue investigated here is the nature of basic action: What is it that counts as the most primitive event which brings about karmic retribution? The debate, primarily revolving around bodily action, places several Buddhist stances in opposition, including the Pudgalavādin view that bodily action is a movement, the Sarvāstivāda claim that it is a shape, and Vasubandhu's own Sautrāntika position that bodily action is an intention (cetanā) which has the body as its object. Of the concepts introduced by chapter 4, one pair is particularly significant: informative and non-informative actions. The former refers to any action that can be observed by beings other than the agent, hence revealing the agent's intention, while the latter indicates internal actions accessible to the agent alone. The second category consists of mental action, which either occurs on its own or alongside a physical or verbal action and which is the crucial element in karmic retribution. Other classifications in this chapter shed light on the varieties of actions. The most conspicuous of these is the standard Buddhist catalog of the ten virtuous and non-virtuous paths of action (karmapatha), where the term "path of action" designates the most severe among the constructive and harmful deeds an agent can undertake. The chapter concludes with a list of the various effects that actions bring about. Vasubandhu, however, avoids the topic of the process by which these effects come about, deferring it to the final part of the $A K B h$.

The topic at the heart of the fifth chapter is the nature of proclivities, or latent dispositions (anuśaya), referring to mental afflictions (kleśa) in their dormant state. Throughout their existence, proclivities remain inactive in the mind, until, under the appropriate causes and conditions, they manifest as active defilements, called "envelopment" (paryavasthāna). Their significance for the Buddhist path lies in the principle that defilements motivate the undertaking of karman, which perpetuates the existence of sentient beings in samsāra. The basic list of proclivities describes six cardinal affects: attachment (raga), hostility (pratigha), ignorance (avidyā), conceit (māna), doubt (vicikitsā), and afflicted views (drșți), which, under detailed scrutiny, yields a longer list of secondary proclivities. A central debate in this chapter concerns the nature of proclivities, on which the Sarvāstivāda and the Sautrāntika are divided. As is typically the case in disagreements of this kind, the Sarvāstivādins consider a proclivity to be an ultimately existent factor (dharma) which exhibits its causal efficacy at a particular moment, when it turns into an "envelopment." Therefore, "proclivity" and "envelopment" are two synonyms for a single factor. Vasubandhu, representing the Sautrāntika position, denies the existence of proclivities as ultimate entities and 
instead explicates them as processes. According to his stance, a proclivity is a force (śākti) within the mental stream that retains its momentum over time, giving rise to the manifest affliction when a particular transformation of the stream occurs. Using the terms of his theory of seeds, Vasubandhu likens the proclivity to a seed (bija) whose gradual development results in a fruit (phala). The question of the temporal maturation of proclivities leads to a subsequent discussion about the existential status of past and future dharmas, wherein the Sarvāstivāda masters seek to demonstrate their quintessential doctrine that not only present factors, but also past and future factors, exist. The Sautrāntika system, objecting again to the reification of unnecessary ontological entities, rejects this stance.

Moving in the direction of the world of awakened beings, the sixth chapter of the $A K B h$ is an account of the stages of the path to liberation from samsāra and the attainments of persons who realize it. The stages of the path (or simply, the paths) are explained with respect to the four noble truths. When discussing these essential teachings, Vasubandhu raises and addresses related misgivings, such as the issue of whether pleasant (sukha) feeling exists and why the first truth relates only to suffering and not to pleasure as well, even though sentient beings also have experiences of pleasure. It is in this chapter, following the exposition of the truths, that Vasubandhu's stock definition of the conventional and ultimate truths is provided. Under the two headings of calm abiding (śamatha) and insight (vipașyanā), Vasubandhu gives a concise, sometimes critical, exposition of core early Buddhist meditative practices, including the meditation on the loathsomeness of the body, mindfulness of breathing, and the four bases of mindfulness. These meditations belong to the first stage of practice, the path of preparation (prayogamārga). Following in order are the path of insight (darśanamārga), the path of cultivation (bhāvanāmārga), and the path of those beyond training (aśaikșamārga). Persons who have attained direct realizations are situated in one of these three stages. Vasubandhu correlates between the three paths, the level of defilements that are purified in each of them, and the fruits achieved by the practitioners, which are the states of the stream-enterer, once-returner, non-returner, and arhat. Another classical explication of the path discussed here is the list of thirty-seven factors that are conducive to awakening (bodhipakșikadharma).

The seventh chapter covers the ten types of knowledge (jñāna) enjoyed by beings who reach the levels of spiritual attainments. These are (1) knowledge of the factors (dharmajñanna), whose objects are the four noble truths in the realm of desire; (2) subsequent knowledge (anvayajñāna), which cognizes the four noble truths of the form and formless realms; (3) mundane conventional knowledge (lokasaṃvrtijñāna), which comprises impure cognitions of conventional objects; (4) knowledge of the minds of others (paracittajñāna), whose object of cognition is the mind moments of other beings; (5) knowledge of suffering (duhkhhajñāna), a pure realization of the impermanence, unsatisfactory nature, emptiness, and selflessness of the five aggregates; (6) knowledge of the origin of suffering (samudayajñāna), which is the realization of the causal function of the five aggregates; (7) knowledge of the cessation of suffering, whose object is the cessation of the five aggregates; (8) knowledge of the path (mārgajñāna), which realizes the liberating function of the five aggregates; (9) knowledge of exhaustion (kșayajñāna), a term that specifically refers to the arhats' knowledge of factors, which is the certainty that the tasks to be accomplished with respect to each of the four truths are being accomplished; and (10) knowledge of non-arising (anutpādajñāna), which is, similarly, a title given to subsequent knowledge when the cognizing person is an arhat which indicates the certainty that comes with the realization that the four tasks no longer need to be pursued. The first part of the seventh chapter elaborates on the characteristics of these types of knowledge and the distinction between them, right view 
(samyagdrștii), and receptivity (kșānti). The latter part deals with the qualities that these forms of knowledge constitute.

Continuing the exposition of spiritual attainments, the eighth chapter focuses on meditative attainments (samāpatti). It gives a detailed description of the levels of absorption (samādhi), including the qualities of the four meditations (dhyāna) connected with the form realm, the four perception spheres (āyatana) connected with the formless realm, and the attainment of cessation (nirodhasamāpatti). Vasubandhu describes three particular types of samādhi: the samādhi of emptiness (śūnyatā), leading to the realization of the emptiness of the self; the samādhi of signlessness (animitta), whose object is nirvana, which is free of characteristics; and the samādhi of wishlessness (apranihita), which leads to the aspiration towards no factor whatsoever. Also discussed in this chapter are the practices of the four immeasurables (apramāna or brahmavihāra) - loving-kindness (maitrī), compassion (karuṇā), joy (muditā), and equanimity (upekșā) - and three other frameworks describing attainments of concentration: the eight liberations (vimukșa), the eight perception spheres of mastery (abhivāyatana), and the ten perception spheres of totality (krtsnāyatana). The final section of the chapter offers concluding comments, indicating that this chapter was originally the final one.

The treatise on the negation of the theory of self, which effectively concludes Vasubandhu's magnum opus, mounts a philosophical attack on two notions of individuality. The first is the one held by followers of the Buddhist personalist school (Pudgalavāda, alternatively known as the Vātsīputrīya or the Sammmitīya), who submit to the existence of a person (pudgala) over and above the five aggregates. This person is neither different from nor identical with the aggregates. The second notion is that of the self (ātman), which is accepted in some form by all six of the Indian orthodox schools. The chapter opens with arguments from reason and scripture against the Pudgalavādin idea of the person. Particularly, Vasubandhu seeks to show the faults in the school's analogy of fire, which suggests that the relationship between the five aggregates and the person is the sort of reliance that exists between fire and fuel. The latter half of the chapter is dedicated to the non-Buddhist concept of the enduring self. Among other things, Vasubandhu addresses objections formulated by Indian orthodox philosophers, most probably belonging to the Nyāya or Sāṃkhya schools, against the Buddhist rejection of the self. These objections concern the compatibility of the no-self doctrine with commonly observable conventions, such as remembering past experiences, carrying out actions (e.g., walking), and the distinction between individual streams of consciousness.

\section{Notable Commentaries}

Due to its thorough, yet refined, presentation of the Sarvāstivāda doctrines, the $A K B h$ earned a place of honor in the lineage of Abhidharma manuals and was the subject of numerous commentaries by Indian, Tibetan, and Chinese scholars. Two classical commentaries composed in India are Yaśomitra's seventh-century Sphuțārthābhidharmakośavyākhyā, which is extant in Sanskrit and included in Shastri's edition (mentioned in the section titled "A Textual History of the Abhidharmakośabhāșya") but has not been translated into European languages, and the Abhidharmakośabhāșyațīkā Tattvārthā by the important sixth-century scholar Sthiramati, extant in its Tibetan translation. Later traditions, particularly the Tibetan, have deemed Yaśomitra's Vyākhyā the paramount Indian commentary on the AKBh. Two earlier commentaries, which Yaśomitra mentions in his Vyākhyā but which have not survived except for a few quotations in 
Yaśomitra's commentary, were written by Gunamati and his student Vasumitra respectively. The Upāyikā-nāmā Abhidharmakośa-Ṭikā, an undated Sanskrit commentary preserved in the Tibetan canon and attributed to the otherwise unknown Samathadeva, is a collection of canonical quotations that appear in the $A K B h$. The author provides a more complete reference to the textual source from which the quotations are drawn, either by providing a full quotation or by indicating the name of the sutra and the place in which the passage can be found. ${ }^{36}$

Another important commentarial work is Purṇavardhana's Lakṣaṇāṇusāriṇi (Minor Commentary) from about the eighth century. His exegesis handles selected topics in an abridged manner, but refers to the opinions of other thinkers. Dignāga, a direct student of Vasubandhu, wrote a commentary entitled the Marmapradipa. This is an abridged version of the $A K B h$, in which Dignāga "reproduces word for word the kārikās [verses] and the basic explanations of the Abhidharmakośa-bhāșya," as Mejor observes. ${ }^{37}$ Mejor's study of the commentaries preserved in the Tibetan canon is a helpful guide to the history of these works and their authors.

The foundational commentary on the $A K B h$ for all schools of Tibetan Buddhism is the Chos mngon pa'i mdzod kyi tshig le'ur byas pa'i 'grel ba mngon pa'i rgyan (The Ornament of Abhidharma), also known by its abbreviated name mChims mdzod (the mChims Treasury), by the Tibetan scholar mChims 'jam dpa'i dbyangs (ca. 1245-1325). ${ }^{38}$ This commentary relies to a considerable extent on notes given in the Indian commentaries by Yaśomitra, Sthiramati, and Purnavardhana. Each of the four Tibetan Buddhist schools has produced commentaries, largely with reference to the $m$ Chims mdzod. The most common Gelug supplement to the $m$ Chims mdzod is the mdzod Tik thar lam gsal byed (Illuminating the Path to Liberation) by the first Dalai Lama, dGe 'dun grub (1391-1474).

In the Kagyu tradition, the commentary mNgon pa mdzod kyi 'grel pa chos mngon rgya mtsho'i snying po (The Essence of the Ocean of Abhidharma) by the Ninth Karmapa, Dbang phyug rdo rje (1556-1603), is the standard reference. However, the Eighth Karmapa, Mi bsyod rdo rje (1507-1554), also wrote an important commentary; namely, Chos mngon pa'i mdzod kyi 'grel pa rgyas par spros pa grub bde'i dpyid 'jo zhes bya ba glegs bam dang po (An Explanation of the Treasury of Abhidharma Called the Essence of the Ocean of Abhidharma, The Words of Those Who Know and Love, Explaining Youthful Play, Opening the Eyes of Dharma, the Chariot of Easy Practice). The standard Sakya commentary is arguably Rong ston shes bya kun rig's Shes bya rab gsal (Thoroughly Illuminating What Can Be Known), while in the Nyingma curriculum, a prominent commentary, Rin po che'i do shal blo gsal dgyes pa'i mgul rgyan (Precious Garland, An Ornament of Joyful Understanding), ${ }^{39}$ was composed by 'Ju mi pham.

In the Chinese tradition, the three major commentaries on the $A K B h$ were composed by three direct disciples of Xuanzang, who translated the $A K B h$ into Chinese: Shentai's commentary, titled Jushe lun shu, Puguang's commentary, Jushe lun ji (Taisho 1821), and Fabao's commentary, Jushe lun shu (Taisho 1822). These commentaries provide valuable information on the ideas found in the $A K B h$, as reflected in La Vallée Poussin's translation. However, modern scholarship has not studied them in their own right.

\section{Review of the Literature}

While some modern studies have exclusively directed their attention to the $A K B h$, it is most often the case that the treatise has been examined as part of a broader thematic investigation surveying 
multiple sources. One of the central issues discussed with respect to the $A K B h$ specifically concerns the sectarian position that Vasubandhu took when composing the text. In a series of publications, Robert Kritzer has sought to demonstrate that by the time he composed the $A K B h$, Vasubandhu had already adhered to the tenets of the Yogācāra school. ${ }^{40}$ An alternative historical reconstruction advanced by Changhwan Park (2014) counters Kritzer's hypothesis, suggesting that the Vasubandhu of the $A K B h$ held pre-Yogācāra views, in alignment with the traditional Buddhist account which describes the author of the $A K B h$ as a follower of non-Mahāyāna schools. ${ }^{41}$ Kritzer's and Park's approach, which inclines towards an intertextual exploration of the $A K B h$ 's doctrines, has been adopted by modern scholarship in various other cases. ${ }^{42}$

Studies in the first decades of the twenty-first century have turned to the $A K B h$ in order to obtain a Buddhist perspective on various problems in the philosophy of action. The chapter on karman - one of the most comprehensive treatments of the topic in classical Buddhist literature - was analyzed by Johannes Bronkhorst in his investigation of the place of teleology in India's mechanistic theory of karman (2000). ${ }^{43}$ Kachru's modern commentary on Vasubandhu's Vimśikā (2015) also presents a philosophical examination of the AKBh's action theory. ${ }^{44}$ Karin Meyers, who sets out to explore the problem of free will and determinism in the light of South Asian Buddhism, draws substantially on Vasubandhu's treatment of intending (cetanā) and action as presented in the chapter on karman. ${ }^{45}$ Finally, Hanner (2016) delineates this chapter's description of the metaphysical mechanism that allows for actions to be undertaken in the absence of an enduring self. ${ }^{46}$

Another research avenue pursued in the literature centers on Indian and Buddhist notions of selfhood and identity. A seminal inquiry into Vasubandhu's critique of the self in the ninth chapter of the $A K B h$ is taken by Kapstein (2001) as part of his study of personal identity in Classical India. ${ }^{47}$ Jonardon Ganeri (2007) analyzes central arguments concerning the nature of persons formulated by Vasubandhu and his opponents, while comparing them to Western theories of personal identity. ${ }^{48}$ The arguments concerning the self have also served as a key source for Mark Siderits's influential reading of the early Buddhist theories of persons developed in various of his works, most prominently in Siderits 2003 and 2015. ${ }^{49}$ A different thematic and cross-textual investigation, which substantially relies on the second chapter of the $A K B h$, is Alexander von Rospatt's (1995) study of the Buddhist doctrine of momentariness. ${ }^{50}$

Being one of the pillars of Vasubandhu's extensive oeuvre, the $A K B h$ has played a central role in the lively twentieth-century debate regarding Vasubandhu's identity. The question leading this debate has been whether the author of the $A K B h$ is the same Vasubandhu who composed the Yogācāra treatises and commentaries. Two important early milestones in this controversy are Frauwallner (1951), ${ }^{51}$ who makes the first claim for acknowledging two authors by the name of Vasubandhu, and Jaini's response (1958). ${ }^{52}$ More recently, Gold (2015) has attempted to highlight philosophical motifs that indicate a continuity of thought between Vasubandhu's Abhidharma and Yogācāra works. ${ }^{53}$

\section{Links to Digital Materials}

The $A K B h$ in Sanskrit and its Chinese and Tibetan translations have been digitized and are available online through dedicated websites. The verse portion of the work (that is, the $A K$ ) was processed by the members of the Sanskrit Buddhist Input Project, which provides a Romanized version of the text, while Hackett and Lusthaus supply a full transliteration of both the verses and 
the self-commentary. The Chinese Buddhist Electronic Text Association (CBETA) gives Xuanzang's translation in Chinese characters. Digitally scanned images of the Tibetan translation are available through the Buddhist Digital Resource Center (BDRC). Baarvig offers a synoptic edition of the $A K B h$, which includes Vasubandhu's Sanskrit, Xuanzang's and Paramārtha's Chinese translations, and portions of the Tibetan translation. Besides digital versions of the primary text, helpful resources are Potter, with a thorough bibliographical list of philosophical studies of the $A K B h$; Saito et al., which surveys the seventy-five dharmas of the Sarvāstivāda and provides illustrations from the $A K B h$ and other Buddhist works; and Korin (Charlie Pokorny), which offers a useful compilation of materials, such as a summary of the $A K B h$ 's content and arguments alongside lists of references to secondary literature, both academic and popular, and various online resources (some of which are no longer active).

Braarvig, Jens, ed. "Vasubandhu: Abhidharmakośabhāṣya." Bibliotheca Polyglota, Thesaurus Literaturae Buddhicae. University of http://www2.hf.uio.no/common/apps/permlink/permlink.php?app=polyglotta\&context=volu me\&uid=9f3907f3-f0ba-11e4-bbf3-001cc4ddf0f4. Accessed May 26, 2020.

Buddhist Digital Resource Center. "Chos mngon pa mdzod kyi bshad pa (Abhidharmakośabhāșya)." https://www.tbrc.org/\#!rid=W1KG11694. Accessed May 26, 2020.

Chinese Buddhist Electronic Text Association (CBETA). "Āpídámó jùshè lùn (Abhidharmakośa)." Dharma Drum Institute of Liberal Arts. https://cbetaonline.dila.edu.tw/en/T1558. Accessed May 26, 2020.

Hackett, Paul and Dan Lusthaus, eds. "Vasubandhu: Abhidharmakosa-bhasya. Based on the editions of P. Pradhan and Dwarikadas Shastri, Swami." GRETIL - Göttingen Register of Electronic Texts in Indian Languages. http://gretil.sub.unigoettingen.de/gretil/1_sanskr/6_sastra/3_phil/buddh/vakobhau.htm. Accessed May 26, 2020.

Korin (Pokorny, Charlie). "Abhidharmakosa Study: Study Materials." Abhidharma Study Blog: Facing the Dharma. https://abhidharmakosa.files.wordpress.com/2010/09/kosa-studymaterials.pdf. Published September 10, 2010.

Members of the Sanskrit Buddhist Input Project. "Vasubandhu: Abhidharmakosa, Karikas only." GRETIL - Göttingen Register of Electronic Texts in Indian Languages. http://gretil.sub.unigoettingen.de/gretil/1_sanskr/6_sastra/3_phil/buddh/vakobhku.htm. Accessed May 26, 2020.

Potter, Karl, ed. "Part I: Texts Whose Authors Can Be Dated, 175.1. Abhidharmakośa and Bhāșya thereon (Sautrāntika) (NCat I, 289-290)." Bibliography of Indian Philosophies. University of Washington. http://faculty.washington.edu/kpotter/xtxt1.htm. Last modified April 15, 2020.

Saito, Akira, Daigo Isshiki, Koichi Takahashi, Toshio Horiuchi, Hisataka Ishida, Kuniori Matsuda, and Shiori ljuin. "Bukkyō yōgo no teigiteki yōrei shū 仏教用語の定義的用例集 (Buddhist Terminology: A Collection of Definitions and Examples)." Bauddha Kośa. http://www.l.utokyo.ac.jp/ b_kosha/html/b_kosha_2014/html/index_75dharma.html. Last modified March $5,2014$.

\section{Further Reading}


Anacker, Stefan. "Vasubandhu, His Life and Times." In Seven Works of Vasubandhu: The Buddhist Psychological Doctor, 7-28. Delhi: Motilal Banarsidass, 1984.

Choepel, David Karma, trans. Jewels from the Treasury: Vasubandhu's Verses on the Treasury of Abhidharma and Its Commentary Youthful Play by the Ninth Karmapa Wangchuk Dorje. Woodstock, NY: KTD, 2012.

Coghlan, lan James, trans. Ornament of Abhidharma: A Commentary on Vasubandhu's Abhidharmakośa. Somerville, MA: Wisdom Publications, 2019.

Cox, Collett. Disputed Dharmas: Early Buddhist Theories on Existence; An Annotated Translation of the Section of Factors Dissociated from Thought from Sanighabhadra's Nyāyānusāra. Tokyo: The International Institute for Buddhist Studies, 1995.

Dhammajoti, Bhikkhu KL. Sarvāstivāda Abhidharma, Third Revised Edition. Hong Kong: Centre of Buddhist Studies, The University of Honk Kong, 2007.

Dhammajoti, Bhikkhu KL. "Summary and Discussion of the Abhidharmakośa-bhāșya." In La Vallée Poussin, Louis de and Gelong Lodrö Sangpo, trans. Abhidharmakośa-Bhāșya of Vasubandhu: The Treasury of the Abhidharma and its (Auto) Commentary, Vol. 1, 1-69. Delhi: Motilal Banarsidass Publishers, 2012.

Duerlinger, James. Indian Buddhist Theories of Persons: Vasubandhu's "Refutation of the Theory of a Self." London; New York: RoutledgeCurzon, 2003.

Gold, Jonathan. Paving the Great Way: Vasubandhu's Unifying Buddhist Philosophy. New York: Columbia University Press, 2015.

Kapstein, Matthew T. Reason's Traces: Identity and Interpretation in Indian and Tibetan Buddhist Thought. Studies in Indian and Tibetan Buddhism. Boston: Wisdom Publications, 2001.

Kritzer, Robert. Vasubandhu and the Yogācārabhūmi: Yogācāra elements in the Abhidharmakośabhāșya. Tokyo: International Institute for Buddhist Studies of the International College for Postgraduate Buddhist Studies, 2005.

La Vallée Poussin, Louis de and Leo M. Pruden, trans. Abhidharmakośabhāṣyam of Vasubandhu. Berkeley, Calif.: Asian Humanities Press, 1988-1990.

La Vallée Poussin, Louis de and Gelong Lodrö Sangpo, trans. Abhidharmakośa-Bhāșya of Vasubandhu: The Treasury of the Abhidharma and its (Auto) Commentary. Delhi: Motilal Banarsidass, 2012.

Takakusu, Junjirō, trans. The Life of Vasubandhu. Leiden: Brill, 1904.

\footnotetext{
${ }^{1}$ See K. L. Dhammajoti, "Summary and Discussion of the Abhidharmakośa-bhāșya," in Louis de la Vallée Poussin and Gelong Lodrö Sangpo, trans, Abhidharmakośa-Bhāșya of Vasubandhu: The Treasury of the Abhidharma and its (Auto) Commentary (Delhi: Motilal Banarsidass, 2012), 10.

2 See Charles Willemen, Bart Dessein, and Collett Cox, Sarvāstivāda Buddhist Scholasticism (Leiden: Brill, 1998), 255269; Dhammajoti (2012), pp. 108-19; and Leo Pruden, "The Abhidharma: The Origins, Growth and Development of a Literary Tradition," in Louis de la Vallée Poussin and Leo M. Pruden, trans, Abhidharmakośabhāṣyam of Vasubandhu (Berkeley, Calif.: Asian Humanities Press, 1988-1990), Vol.1, liii-liv.

3 See Welleman, Dessein, and Cox (1998), 18-19. On the history and development of the Abhidharma literature more broadly and the extant Abhidharma treatises, see Ulrich T. Kragh, "The Extant Abhidharma-Literature," The Indian International Journal of Buddhist Studies 3 (2002): 123-167.
} 
${ }^{4}$ On this, as well as on other contemporaneous authors whose work influenced the $A K B h$, see Marek Mejor, Vasubandhu's Abhidharmakośa and the Commentaries Preserved in the Tanjur (Stuttgart: Franz Steiner Verlag, 1991), 13-18.

${ }^{5}$ On which, see Collett Cox's seminal study, Disputed Dharmas: Early Buddhist Theories on Existence; An Annotated Translation of the Section of Factors Dissociated from Thought from Sanighabhadra's Nyāyānusāra (Tokyo: The International Institute for Buddhist Studies, 1995).

${ }^{6}$ See Welleman, Dessein, and Cox (1998), 272-273.

${ }^{7}$ On the transmission of the $A K B h$ to Tibet, see lan James Coghlan, "Translator's Introduction," in lan James Coghlan, trans, Ornament of Abhidharma: A Commentary on Vasubandhu's Abhidharmakośa (Somerville, MA: Wisdom Publications, 2019), 14-18.

8 Yaśomitra, Sphuțārthā Abhidharmakośavyākhyā, ed. Unrai Wogihara (Tokyo: The Publishing Association of Abhidharma-kośa-vyākhyā, 1932-1936).

9 V. V. Gokhale, "The Text of the Abhidharmakośakārikā of Vasubandhu," Journal of the Bombay Branch of the Royal Asiatic Society 22 (1946): 73-102.

10 Vasubandhu, Abhidharma-kośabhāșya of Vasubandhu, ed. Prahlad Pradhan (Patna: K. P. Jayaswal Research Institute, 1967).

11 Vasubandhu, Abhidharma-kośabhāșya of Vasubandhu, ed. Prahlad Pradhan Arun Haldar, was published in 1975 by the same publisher. Electronic texts based primarily on Pradhan's second edition have been published online by the GRETIL project, edited by Paul Hackett and Dan Lusthaus (http://gretil.sub.unigoettingen.de/gretil/1_sanskr/6_sastra/3_phil/buddh/vakobhau.htm), and by the Bibliotheca Polyglota project, edited by Jens Braarvig, which also offers a helpful synoptic edition that includes the Sanskrit, the two Chinese translations, and, at the time of writing, a limited portion of the Derge edition of the Tibetan translation (http://www2.hf.uio.no/common/apps/permlink/permlink.php?app=polyglotta\&context=volume\&uid=9f3907f3-f0ba11e4-bbf3-001cc4ddf0f4).

12 Vasubandhu and Yaśomitra, Abhidharmakoșa \& Bhāșya of Acharya Vasubandhu with Sphutārthā Commentary of Ācārya Yaśomitra, ed. Swami Dwarikadas Shastri (Varansi: Bauddha Bharati, 1970-1973).

13 Vasubandhu, Abhidharmakośabhāșya of Vasubandhu, chapter IX: Ātmavādapratiședha. Bibliotheca Indologica Buddhologica 11, ed. Jong Schoel Lee, with critical notes by Yasunori Ejima (Tokyo: Sankibo Press, 2005).

${ }^{14}$ Kyokuga Saeki, Kandō Abidatsumakusharon (Kyoto: Hōzōkan, 1978).

${ }^{15}$ Vasubandhu, L'Abhidhramkośa de Vasubandhu, trad. et annoté Louis de la Vallée Poussin (Paris: Paul Geuthner; Louvain: J. B. Istas, 1923-1931).

${ }^{16}$ Leo M. Pruden (1988-1990), lix.

17 Vasubandhu, Abhidharmakośabhāșyam of Vasubandhu, trans. Louis de la Vallée Poussin and Leo M. Pruden (Berkeley, Calif.: Asian Humanities Press, 1988-1990).

${ }^{18}$ Vasubandhu, Abhidharmakośa-Bhāșya of Vasubandhu: The Treasury of the Abhidharma and lts (Auto) Commentary, trans. Louis de la Vallée Poussin and Gelong Lodrö Sangpo (Delhi: Motilal Banarsidass, 2012).

19 Vasubandhu and Wangchuk Dorje, Jewels from the Treasury: Vasubandhu's Verses on the Treasury of Abhidharma and Its Commentary Youthful Play by the Ninth Karmapa Wangchuk Dorje, trans. David Karma Choephel (Woodstock, NY: KTD Publications, 2012).

20 Masahiro Shōgaito, The Uighur Abhidharmakośabhāșya: Preserved at the Museum of Ethnography in Stockholm (Wiesbaden: Harrassowitz, 2014).

${ }^{21}$ Theodore Stcherbatsky, "The Soul Theory of the Buddhists," Bulletin de l'Academie des Sciences de Russie 13, no. 12-15 (1919): 823-854 and no. 16-18 (1919): 937-958. Reprinted as Theodore Stcherbatsky, The Soul Theory of the Buddhists (Delhi: Bharatiya Vidya Prakashan, 1976), with several further reprints.

${ }^{22}$ Matthew T. Kapstein, Reason's Traces: Identity and Interpretation in Indian and Tibetan Buddhist Thought (Boston, MA: Wisdom Publications, 2001), 347-374.

23 James Duerlinger, Indian Buddhist Theories of Persons: Vasubandhu's "Refutation of the Theory of a Self" (London; New York: RoutledgeCurzon, 2003). An earlier version of this translation was published as James Duerlinger, "Vasubandhu's 'Refutation of the Theory of Selfhood' (Ātmavādapratiședha)," Journal of Indian Philosophy 17, no. 2 (1989), 129-187. The first half of the translation (the debate with the Pudgalavādins) was also republished as James Duerlinger, "Vasubandhu's Abhidharmakośa: The Critique of the Pudgalavādins' Theory of Persons," in Buddhist 
Philosophy: Essential Readings, eds. William Edelglass and Jay L. Garfield (Oxford: Oxford University Press, 2009), 286-296.

${ }^{24}$ Charles Goodman, "Vasubandhu's Abhidharmakośa: The Critique of the Soul," in Buddhist Philosophy: Essential Readings, eds. William Edelglass and Jay L. Garfield (Oxford: Oxford University Press, 2009), 297-308.

25 Taiken Kimura and Unrai Wogihara, Abidatsumakusharon, Kokuyako Daizōkyō, Ron-bu, vol. 11-13 (Tokyo: Kokumin Bunko Kankōkai, 1920); Giyū Nishi, Abidatsumakusharon, Kokuyaku Issaikyō: Indo senjutsubu, 4th ed., Bidon-bu, vol. 25-26 (Tokyo: Daitō Shuppansha, 1999 [1935]).

${ }^{26}$ Hajime Sakurabe 櫻部建. Kusharon no kenkyū: Kai, konhon. 俱舎論の研究【界・根品】 (Kyoto: Hōzōkan, 1969); Susumu Yamaguchi 山口益 and Issai Funahashi 舟橋一哉. Kusharon no genten kaimei: Sekenbon 俱舎論の原典解明 【世間品】(Kyoto: Hōzōkan, 1955); Issai Funahashi 舟橋一哉. Kusharon no genten kaimei: Gōbon 俱舎論の原典解明 【業品】(Kyoto: Hōzōkan, 1987); Nobuchiyo Odani 小谷信千代 and Yoshifumi Honjō 本庄良文. Kusharon no genten kaimei: Zuiminbon 俱舎論の原典解明【随眠品】 (Kyoto: Daizō Shuppan, 2007); Hajime Sakurabe 櫻部建 and Nobuchiyo Odani 小谷信千代. Kusharon no genten kaimei: Genjō bon 俱舎論の原典解明【賢聖品】 (Kyoto: Hōzōkan, 1999); Sakurabe Hajime 櫻部建, Odani Nobuchiyo 小谷信千代, and Honjō Yoshifumi 本庄良文. Kusharon no genten kaimei: Chihon, Jōhon 俱舎論の原典解明【智品·定品】(Kyoto: Daizō Shuppan, 2004).

${ }^{27}$ Akira Hirakawa 平川彰 in collaboration with Shunei Hirai, So Takahashi, Noriaki Hakamaya, and Giei Yoshizu, Index to the Abhidharmakośa-bhāșyam (P. Pradhan Edition) (Tokyo: Daizō Shuppan, 1973-1978).

${ }^{28}$ Akira Saito 斎藤明, Daigo Isshiki, Koichi Takahashi, Toshio Horiuchi, Hisataka Ishida, Kuniori Matsuda, and Shiori ljuin, The Seventy-Five Elements (dharma) of Sarvāstivāda in the Abhidharmakośabhāşya and Related Works, Bauddhakośa: A Treasury of Buddhist Terms and Illustrative Sentences, vol. 6 (Tokyo: The International Institute for Buddhist Studies of the International College for Postgraduate Buddhist Studies, 2018).

${ }^{29}$ http://www.I.u-tokyo.ac.jp/ b_kosha/html/b_kosha_2014/html/index_75dharma.html.

30 See K. L. Dhammajoti (2012), 7-9.

31 See Welleman, Dessein, and Cox (1998), 273.

32 Issai Funahashi, "Abhidharmakosa-sastra," Encyclopedia of Buddhism, ed. Gunapala Piyasena Malalasekera ([Colombo:] Government of Ceylon, 1961), vol. 1, p. 59.

${ }^{33}$ For a study of this chapter, see Bruce Cameron Hall, "Vasubandhu on 'Aggregates, Spheres, And Components': Being Chapter One Of The 'Abhidharmakośa”' (PhD Dissertation, Harvard University 1983).

${ }^{34}$ As part of the discussion on conditioned factors dissociated from the mind, Vasubandhu attends to the attainment of cessation. For a study of Vasubandhu's treatment with reference to later commentaries, see Paul Griffiths, "On Being Mindless: The Debate on the Reemergence of Consciousness from the Attainment of Cessation in the Abhidharmakośabhāșyam and Its Commentaries," Philosophy East and West 33, no. 4 (1983): 379-394, and Paul Griffiths, On Being Mindless: Buddhist Meditation and the Body-Mind Problem. La Salle, Illinois: Open Court, 1986.

${ }^{35}$ For a study of Vasubandhu's explanation of the theory of dependent origination, see Susan Stalker, "A Study of Dependent Origination: Vasubandhu, Buddhaghosa, and the Interpretation of 'Pratītyasamutpāda"' (PhD Dissertation, University of Pennsylvania, 1987).

${ }^{36}$ An annotated translation of the Upāyikā-nāmā Abhidharmakośa-Ṭikā into Japanese is Yoshifumi Honjō 本庄良文. Kusharon Chū Upāikā No Kenkyū 俱舎論註ウパーイカーの研究. 2 vols. Tokyo: Daizō Shuppan 大蔵出版, 2014. Along the same lines, Part I of Hirakawa et al. (1973-1978) lists the canonical sources that are explicitly named in the $A K B h$ (pp. 423-425). Two other resources which offer information on identified canonical passages in Vasubandhu's work are Bhikkhu Pāsādika, ed. Kanonische Zitate im Abhidharmakośabhāșya des Vasubandhu, Sanskrit-Wörterbuch der buddhistischen Texte aus den Turfan-Funden (Göttingen: Vandenhoeck und Ruprecht, 1989) and Yoshifumi Honjō 本 庄良文. A Table of Āgama-Citations in the Abhidharmakośa and the Abhidharmakoșpāyikā [sic] 俱舎論所依阿含全表 (Kyoto: private publication, 1984).

37 Marek Mejor (1991), 76.

38 Translated in Ian James Coghlan, trans, Ornament of Abhidharma: A Commentary on Vasubandhu's Abhidharmakośa (Somerville, MA: Wisdom Publications, 2019).

39 See Coghlan (2019), 19-21, for a list of major Tibetan commentaries.

40 Robert Kritzer, Vasubandhu and the Yogācārabhūmi: Yogācāra Elements in the Abhidharmakośabhāṣya. Tokyo: International Institute for Buddhist Studies of the International College for Postgraduate Buddhist Studies, 2005; Robert 
Kritzer, "Quotations Common to the Yogācārabhūmi and the Abhidharmakośa-Bhāsya," Indogaku Bukkyōgaku kenkyū 45, no. 1 (1996): 15-20; Robert Kritzer, "Preliminary report on a comparison of the Abhidharmakosabhasya and the Yogācārabhūmi," Journal of Indian and Buddhist Studies 49.1 (2000), 8-12; Robert Kritzer, "Sautrāntika in the Abhidharmakośabhāsya," Journal of the International Association of Buddhist Studies 26, no. 2 (2003): 331-384.

${ }^{41}$ Changhwan Park, Vasubandhu, Śrīāta, and the Sautrāntika Theory of Seeds. Wiener Studien zur Tibetologie und Buddhismuskunde 84 (Wien: Arbeitskreis für Tibetische und Buddhistische Studien, Universität Wien, 2014).

42 See Marek Mejor, "Vasubandhu's Abhidharmakosa in Non-Buddhist Philosophical Treatises," in Buddhist Studies: Papers of the $12^{\text {th }}$ World Sanskrit Conference, eds. Richard Gombrich and Cristina Scherrer-Schaub (Delhi: Motilal Banarsidass, 2008), 119-150; Johannes Bronkhorst, "Sāṃkhya in the Abhidharmakośa Bhāșya," Journal of Indian Philosophy 25 (1997), 393-400; Shoryu Katsura, "Some cases of doctrinal proofs in the Abhidharmakośabhāṣya," Journal of Indian Philosophy 31 (2003), 105-120.

43 Johannes Bronkhorst, Karma and Teleology: A Problem and Its Solutions in Indian Philosophy (Tokyo: The International Institute for Buddhist Studies of the International College for Advanced Buddhist Studies, 2000), 67-75. See also Bronkhorst's introductory exposition in Karma (Honolulu: University of Hawai'i Press, 2011), 55-88. James McDermott offers a descriptive overview of the chapter in James Paul McDermott, Development in the Early Buddhist Concept of Kamma/Karma (New Delhi: Munshiram Manoharlal, 1984), 127-143.

44 Sonam Kachru, Minds and Worlds: A Philosophical Commentary on the Twenty Verses of Vasubandhu (PhD Dissertation, University of Chicago, 2015), pp. 448-495.

${ }^{45}$ Karin Meyers, Freedom and self-control: Free will in South Asian Buddhism (PhD Dissertation, University of Chicago, 2010). See also Karin Meyers, "Free Persons, Empty Selves: Freedom and Agency in Light of the Two Truths," in Free Will, Agency and Selfhood in Indian Philosophy, ed. Matthew R. Dasti and Edwin F. Bryant (Oxford: Oxford University Press, 2014), 41-67; and Karin Meyers, "The Dynamics of Intention, Freedom, and Habituation according to Vasubandhu's Abhidharmakośabhāșya," in A Mirror is for Reflection: Understanding Buddhist Ethics, ed. Jake H. Davis (Oxford: Oxford University Press, 2017), 239-256.

46 Oren Hanner, Moral Agency under the No-Self Premise: A Comparative Study of Vasubandhu and Derek Parfit (PhD Dissertation, Hamburg University, 2016)

47 Kapstein (2001).

48 Jonardon Ganeri, The Concealed Art of the Soul: Theories of Self and Practices of Truth in Indian Ethics and Epistemology (Oxford: Oxford University Press, 2007).

49 Mark Siderits, Personal Identity and Buddhist Philosophy: Empty Persons, first edition (Aldershot: Ashgate, 2003); Mark Siderits, Personal Identity and Buddhist Philosophy: Empty Persons, second edition (Aldershot: Ashgate, 2015).

50 Alexander von Rospatt, The Buddhist Doctrine of Momentariness: A Survey of the Origins and Early Phase of this Doctrine up to Vasubandhu (Stuttgart: Franz Steiner Verlag, 1995).

${ }^{51}$ Erich Frauwallner, On the Date of the Buddhist Master of the Law Vasubandhu. Serie Orientale Roma III (Rome: Istituto italiano per il Medio ed Estremo Oriente, 1951).

52 Padmanabh S. Jaini, "On the Theory of the Two Vasubandhus," Bulletin of the School of Oriental and African Studies 21 (1958): 48-53.

53 Jonathan Gold, Paving the Great Way: Vasubandhu's Unifying Buddhist Philosophy (New York: Columbia University Press, 2015). 